\title{
Amniotic membrane graft after excision of widespread conjunctival concretions
}

\section{Enxerto de membrana amniótica após remoção de concreções conjuntivais}

Margarida Costa e Silva Sena Brízido ${ }^{1}$ (D), Beatriz de Oliveira Lopes $^{1}$ (D), Ana Catarina Rodrigues Almeida ${ }^{1}(\mathbb{C}$, Margarida Maria Domingas Isidoro Miranda ${ }^{1}$ (i), Ícaro Perez Soares ${ }^{1}$ (d)

Keywords:

Conjunctival diseases/surgery;

Amnion/transplantation;

Conservative treatment; Fibrin

tissue adhesive/therapeutic use

Descritores:

Doenças da túnica conjuntiva/ cirurgia; Âmnio/transplante;

Tratamento conservador;

Adesivo tecidual de fibrina/uso

terapêutico

Received on:

Sep 6, 2020

Accepted on:

Oct 28, 2020

Corresponding author: Margarida Brízido
Av. Carlos Teixeira, $n^{\circ} 3,2674-514$ Loures, Portugal. E-mail: margarida.brizido@hbeatrizangelo.pt

Institution: Hospital Beatriz Ângelo, Loures, Lisbon, Portugal.

Conflict of interest: no conflict of interest.

Financial support: the authors received no financial support for this work.

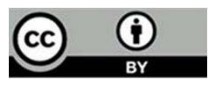

Copyright (C)2021

\begin{abstract}
Conjunctival concretions are single or clustered lesions frequently found on the palpebral conjunctiva. They are commonly present in older individuals, despite being rarely symptomatic. This case report describes an 83-year-old man with multiple conjunctival concretions, which were surgically treated. The patient was symptomatic on presentation and did not respond to conservative treatment. For this reason, a surgical approach was considered. After wide excision of the conjunctival lesions, a piece of amniotic membrane was fitted using fibrin glue. During follow-up, a markedly improvement in patient's symptoms was observed, along with nearly complete absence of conjunctival concretions. This is the first case report addressing extensive conjunctival concretions with a surgical approach using amniotic membrane. The authors conceived the technique described after noticing the limited clinical options in the literature. This technique was easily performed and achieved satisfactory results.
\end{abstract}

\section{RESUMO}

As concreções conjuntivais representam lesões amareladas, simples ou múltiplas, frequentemente encontradas na conjuntiva palpebral. São mais prevalentes em idades avançadas e raramente sintomáticas. Este relato de caso descreve o quadro clínico de um paciente de 83 anos com múltiplas concreções conjuntivais, cirurgicamente tratadas. Por se tratar de um paciente sintomático com resposta insuficiente ao tratamento conservador, foi considerada a abordagem cirúrgica. Após remoção das lesões, foi aplicado um enxerto de membrana amniótica, adaptado com cola de fibrina. No acompanhamento pós-operatório, verificou-se melhoria significativa dos sintomas, com desaparecimento quase total das concreções conjuntivais. Este é o primeiro caso que descreve uma abordagem cirúrgica com utilização de membrana amniótica na resolução desse tipo de lesões. A técnica, de fácil execução e com resultados muito favoráveis, foi desenvolvida pelos autores após constatarem a escassez de alternativas na literatura. 


\section{INTRODUCTION}

Conjunctival concretions are minute hard yellow lesions, frequently found on the palpebral conjunctiva. ${ }^{(1)}$ They may be single or present as clusters of multiple lesions, commonly associated with older age or chronic inflammatory conditions, ${ }^{(2)}$ namely keratoconjunctivitis, meibomian gland dysfunction, post-trachomatous degenerations and sulphadiazine eyedrop administration. ${ }^{(3)}$

Although concretions are frequently referred as lithiasis, the term is a misnomer: transmission electron microscopy showed absence of a crystalline pattern and histological studies have failed to reveal the presence of calcium in these deposits. ${ }^{(4)}$

Previous researchers reported occurrence of conjunctival concretions in $39 \%$ to $42 \%$ of evaluated patients, with only $6 \%$ to $7 \%$ of them being symptomatic. ${ }^{(3,5)}$ The most frequently described symptoms include foreign body sensation, local irritation or ocular discomfort.

In this report, we aimed to describe a case of severe conjunctival concretions surgically treated. Collection and evaluation of protected health information were in accordance with the general principles outlined in the Declaration of Helsinki in its latest version (Brazil, 2013) and complied with the principles of Good Clinical Practice. Written informed consent to publish patient's images and his relevant medical history was obtained from the patient.

\section{CASE REPORT}

An 83-year-old man with irrelevant past medical history presented with intermittent bilateral ocular foreign body sensation and tearing for the last year, with no other associated symptoms. The patient denied use of any ocular medications except from artificial tears. His past ocular history was remarkable for uneventful bilateral cataract extraction and intraocular lens insertion, three years before.

Visual acuity was 20/20 in his right eye and 20/25 in his left eye. Slit lamp examination revealed both anterior and posterior severe blepharitis, discrete medial ectropion, and bilateral multiple confluent upper eyelid conjunctival concretions (Figure 1), causing a superficial punctate keratitis. Lower eyelids were also affected by concretions, albeit in a milder degree.

Herbert pits were notably absent and there were no signs of conjunctival scarring nor trichiasis. The patient was treated for his blepharitis and prescribed with warm compresses and eyelid scrubs, and was advised

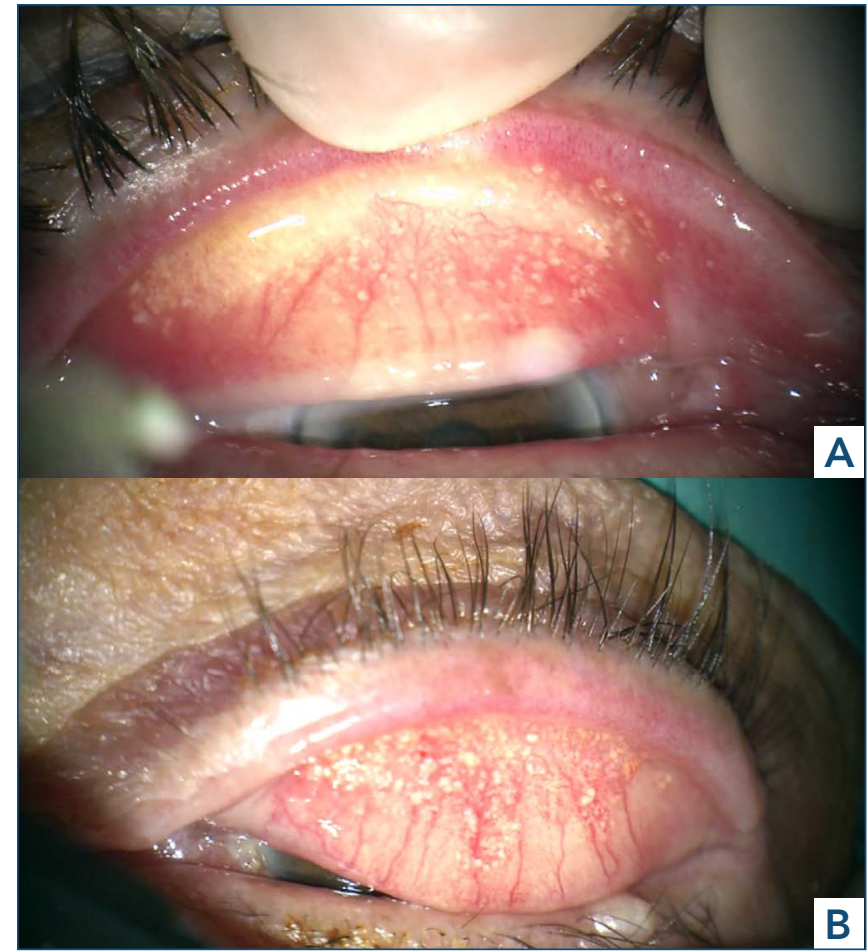

Figure 1. Right (A) and left (B) upper eyelids before surgery.

to keep applying lubricating eye drops daily. After 3 months of treatment, symptoms had not subsided despite a slight improvement in blepharitis severity. He initiated on topical ocular antibiotics (1.5\% azithromycin eye drops, twice daily, later replaced by $0.3 \%$ gentamicin ointment, three times per day) and a 7-day trial of nasal mupirocin ointment was also performed. ${ }^{(6,7)}$ Regardless of blepharitis improvement, symptoms had not yet been appropriately controlled. Upper lid conjunctival concretions were still present, some of them protruding through the conjunctival epithelium and causing sustained inflammation and punctate de-epithelization of the upper cornea.

Surgical excision was then considered. Given the widespread distribution and high number of tarsal lesions, in-office simple excision using a needle would not be practical nor ideal. For this reason, the procedure was performed in the operating room, combining multiple surgical techniques. After topical anesthesia with $0.4 \%$ oxybuprocaine hydrochloride, periocular skin was disinfected with 10\% povidone-iodine and both eyes were draped. Local anesthesia was also used, with injection of $2 \%$ lidocaine mixed with 1:100,000 epinephrine both into the upper eyelid skin and conjunctiva. After eversion of the upper lid, conjunctival concretions were scraped off using a no.15 blade, allowing for removal of the great majority of them. 
A 30-gauge needle was later used, to remove the last resistant lesions (Figure 2A). Using a caliper, the bare area of scraped conjunctiva was measured (to predict the amount of required membrane) and then covered with fibrin glue. Immediately after, a piece of amniotic membrane was spread over the glue with its epithelial side up and cut to the appropriate size (Figure 2B).

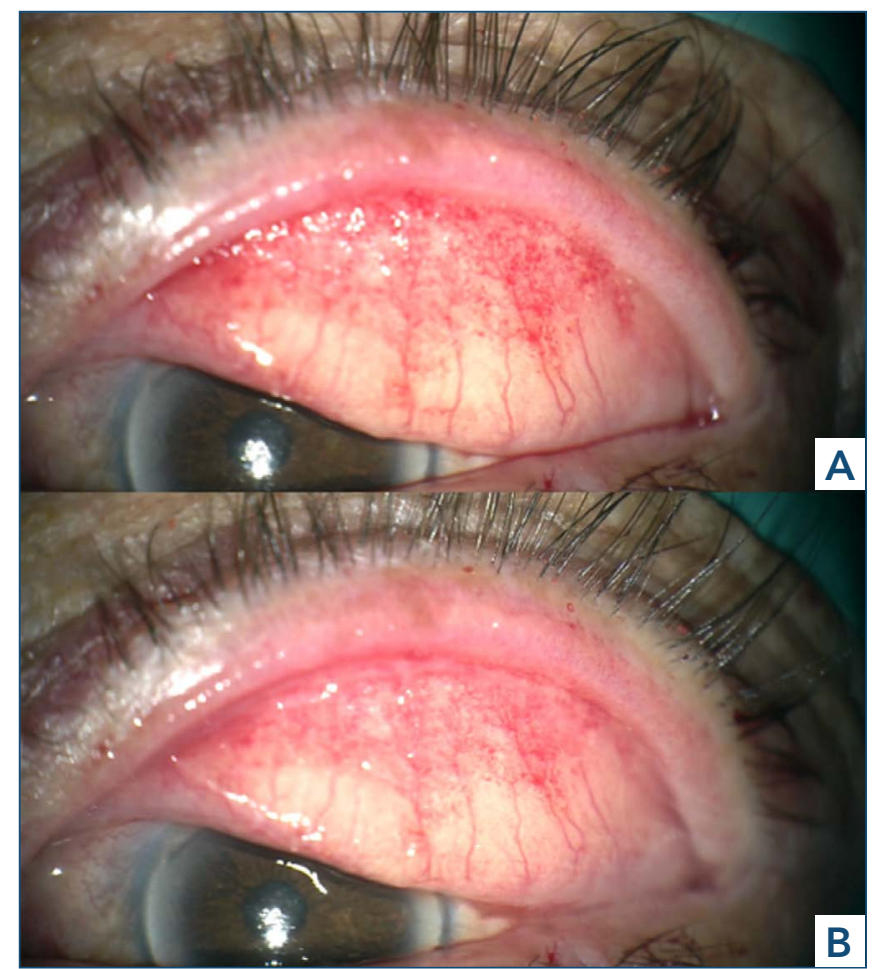

Figure 2. Left upper eyelid after removal of concretions (A) and after placing of amniotic membrane (B)

A few minutes later, when the membrane was firmly attached, the upper eyelid was flipped back to its normal position. The same procedure was used to approach the second eye. The patient was discharged on the same day of surgery and kept under topical antibiotic/steroid combination therapy for 7 days.

At first week follow-up appointment, a markedly improvement in symptoms was noticed. He described no foreign body sensation and a great reduction in tearing. Slit lamp examination revealed nearly complete absence of conjunctival concretions and reabsorption of the amniotic membranes (Figure 3).

During the follow-up period of 12 months, superior corneal epithelial defect disappeared and only a discrete haziness remained in the superior cornea. Upper eyelid eversion revealed residual amounts of single conjunctival concretions, with no evidence of active inflammation (Figure 4).

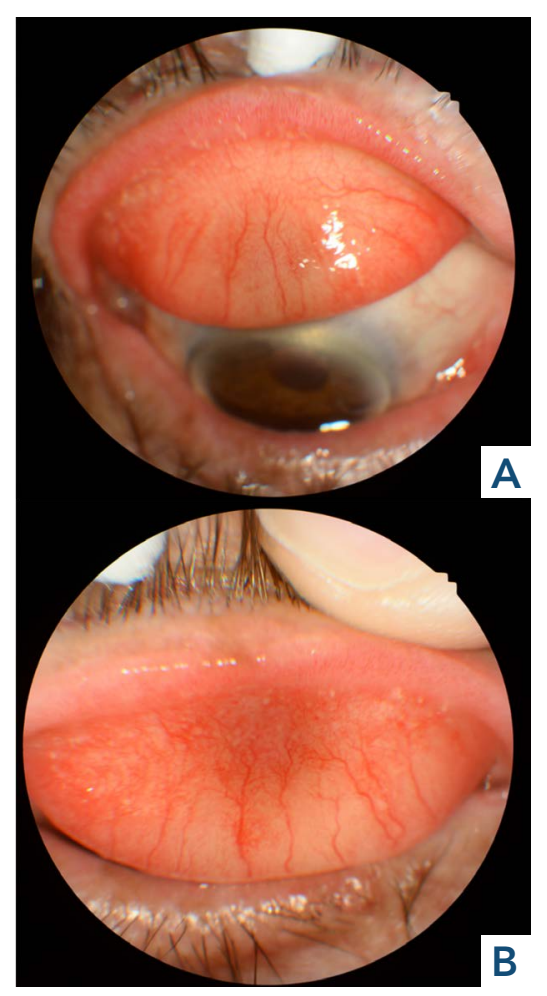

Figure 3. Right (A) and left (B) upper eyelids one week after surgery.

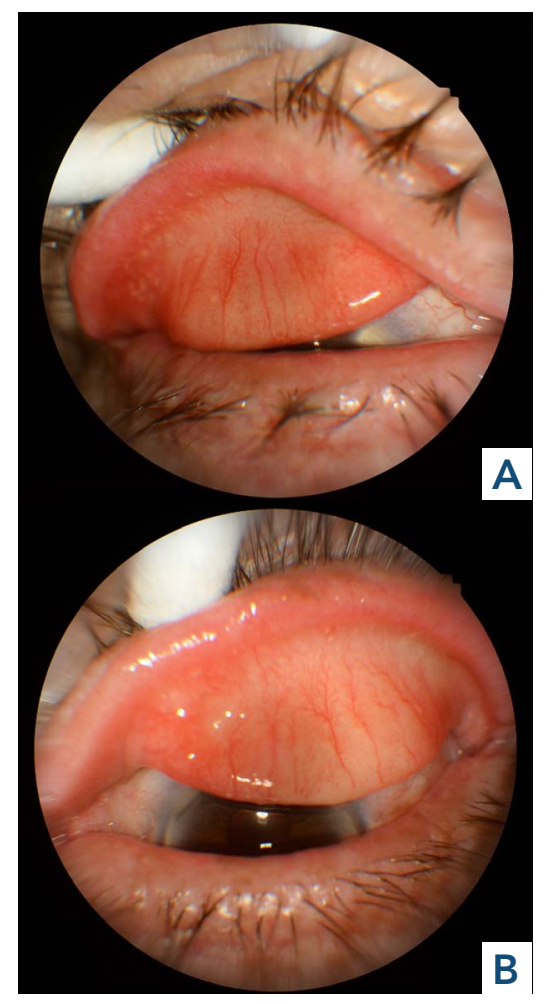

Figure 4. Right (A) and left (B) upper eyelids 12 months after surgery. 


\section{DISCUSSION}

Conjunctival concretions are a quite common incidental finding, occasionally related to symptomatic ocular irritation, and usually associated with a chronic inflammatory reaction. Evidence from previous studies suggests that concretions are mostly composed of degenerative epithelial debris, combined with mucinous secretions from conjunctival glands. ${ }^{(2)}$ Histologically, they contain an amorphous eosinophilic material that stains positive for mucin and neutral mucopolysaccharides. ${ }^{(2,3)}$ Most cases of symptomatic conjunctival concretions can easily be solved by single removal of protruding lesions. However, more severe cases require a distinct approach, addressing the multifocal aspect of the disease. Considering the diffuse presentation of our patient's disease, scraping of lesions was the designated method of choice, for its practical and quicker application. Following removal of most lesions, we decided to cover the bare area with amniotic membrane. This tissue, retrieved from placental donors undergoing elective caesarean section, ${ }^{(8)}$ is the innermost layer of the fetal membranes, composed of a single layer of epithelial cells that lie on a basement membrane, and of a non-vascular collagenous stroma. ${ }^{(9)}$ It has well-known anti-inflammatory and antifibrotic properties, promoting rapid healing and acting as an effective material for wound dressing. ${ }^{(8)}$ Since our patient was left with a large area of denuded conjunctiva, the amniotic membrane was placed to promote proper healing and epithelization, and simultaneously preventing fibrosis.

\section{CONCLUSION}

To the authors' knowledge, this is the first case report addressing extensive conjunctival concretions with a surgical approach using amniotic membrane. The literature has limited clinical options for patients with similar disease presentation. For this reason, we conceived the described technique, which was easily performed and achieved satisfactory results in the short run. Since the follow-up period is still short, relapse and long-term efficacy remain to be determined.

\section{REFERENCES}

1. Sihota R, Tandon R. Parsons' diseases of the eye. 22nd ed. Haryana, India: Elsevier; 2015. p. 184

2. Chang SW, Hou PK, Chen MS. Conjunctival concretions. Polarized microscopic, histopathologic, and ultrastructural studies. Arch Ophthalmol. 1990;108(3):405-7.

3. Kulshrestha MK, Thaller VT. Prevalence of conjunctival concretions [letter]. Eye (Lond). 1995;9(Pt 6):797-8.

4. Kowal VO, Adamis AP, Albert DM. Conjunctival concretions [letter]. Am J Ophthalmol. 1992;114(5):640-1.

5. Haicl P, Janková H. [Prevalence of conjunctival concretions]. Cesk Slov Oftalmol. 2005;61(4):260-4. Czech.

6. Alexandrou TJ, Hariprasad SM, Benevento J, Rubin MP, Saidel M, Ksiazek $S$, et al. Reduction of preoperative conjunctival bacterial flora with the use of mupirocin nasal ointment. Trans Am Ophthalmol Soc. 2006;104:196201

7. Trautmann M, Stecher J, Hemmer W, Luz K, Panknin HT. Intranasal mupirocin prophylaxis in elective surgery. A review of published studies. Chemotherapy. 2008;54(1):9-16.

8. Jirsova K, Jones GL. Amniotic membrane in ophthalmology: properties, preparation, storage and indications for grafting - a review. Cell Tissue Bank. 2017:18(2):193-204.

9. Waked N, El-Kazzi V. [Amniotic membrane utilization in ophthalmological surgical procedures]. J Med Liban. 2005;53(1):39-44. French. 